\title{
De novo designed lactoferrin-oleic acid-loaded chitosan nanoparticles with improved activity and selectivity toward four human cancer cells as compared to conventional complexes
}

\author{
Nawal Abd EL-Baky ${ }^{1 *}$, Marwa Mohamed Abu-Serie ${ }^{2}$, ELRashdy Moustafa Redwan ${ }^{3}$ \\ 'Protective and Therapeutic Proteins Laboratory, Protein Research Department, Genetic Engineering and Biotechnology Research Institute, City of \\ Scientific Research and Technological Applications, Alexandria, Egypt. \\ ${ }^{2}$ Medical Biotechnology Department, Genetic Engineering and Biotechnology Research Institute, City of Scientific Research and Technological \\ Applications, Alexandria, Egypt. \\ ${ }^{3}$ Biological Sciences Department, Faculty of Science, King Abdulaziz University, Jeddah, Saudi Arabia.
}

\section{ARTICLE INFO \\ Received on: 11/11/2020 \\ Accepted on: 02/01/2021 \\ Available online: 05/03/2021}

Key words:

Anticancer, camel and human lactoferrins, nanocomplexes, oleic acid.

\begin{abstract}
Considering the oleic acid (OA) adverse effects on normal and cancer cells besides the less significant anticancer activities of free lactoferrins, this study aimed to formulate camel lactoferrin-OA or human lactoferrin-OA complexesloaded chitosan nanoparticles that achieved cytotoxicity and apoptotic effect on four human cancer cells (Hela, HepG2, Caco-2, and MCF-7) while sparing normal healthy WI-38 cells. Cytotoxicity of these de novo nanoformulations was detected by the 3-(4,5-dimethylthiazol-2-yl)-2,5-diphenyltetrazolium bromide (MTT) assay. Their apoptotic effect was assessed using multiple staining; acridine orange, ethidium bromide, propidium iodide (PI), and annexin V besides the immunocytochemical nuclear staining protocol for $\mathrm{Ki}-67, \mathrm{Bcl}-2$, and $\mathrm{p} 53$. The increment in reactive oxygen species (ROS) manufacture was determined in treated cancer cell lines. Contrary to their corresponding complexes, nanocomplexes showed half maximal inhibitory concentrations $\left(\mathrm{IC}_{50}\right)$ against tumor cells that were significantly $(p$ $<0.05$ ) lower than their safe doses (concentration achieving 100\% cell viability, EC100) against WI-38, indicating their selective targeting of tumor cells. The nanoformulated complexes were more effective at inducing apoptosis and ROS increase in tumor cells than their corresponding complexes. A significant decrease in the levels of Ki-67 and Bcl-2 was found, while p53 level was increased in nanocomplexes-treated cancer cells. These findings suggest that nanoformulation of lactoferrin and OA potentiates their activity and selectivity toward cancer cells.
\end{abstract}

\section{INTRODUCTION}

The glycoprotein of lactoferrin (Lf) represents a milkderived multipurpose iron chelator that also exists in other mammalian cell secretions, for instance, saliva and tears, in addition to vaginal and seminal fluids (Ward et al., 2002). Some clinical studies confirmed the presence of proteins that prevent cancer in

\section{${ }^{*}$ Corresponding Author}

Nawal Abd EL-Baky, Protective and Therapeutic Proteins Laboratory, Protein Research Department, Genetic Engineering and Biotechnology Research Institute, City of Scientific Research and Technological Applications, Alexandria,Egypt.E-mail: nawalabdelbaky83@gmail.com milk (Tsuda et al., 2002). Lactoferrin has been assigned with its suppressing effect on cancer cells propagation in addition to its anticarcinogenic, antioxidant, and anti-inflammatory capabilities in vitro and in vivo (Matsuda et al., 2006; Pan et al., 2007).

More remarkably, it has been found that the Lf gene downregulation might be linked with elevated breast tumors' incidence rates (Furmanski et al., 1989). Also, the exogenous Lf as well as its variants supply could proficiently suppress the growth of cancer in vitro and in vivo (Xu et al., 2010; Yamada et al., 2008). Bovine lactoferrin was proven to have an in vitro anticancer effect on many breast cancer cells and gastric tumor cells (Amiri et al., 2015; Zhang et al., 2015b). Nevertheless, the exact mechanisms by which lactoferrin performs its cytotoxicity activity against cancer cells are still quite unknown. 
Recently, Fang et al. (2014) formed an antitumor complex from Lf and OA that was similar to the complex consisting of human $\alpha$-lactalbumin and OA (HAMLET). They demonstrated that the bLf-OA complex prompts apoptosis in tumor cell lines, thus inducing high antitumor activity. The interaction of both lactoferrin and $\alpha$-lactalbumin with oleic acid was found to be via van der Waals forces in addition to hydrogen bonding, but $\mathrm{Lf}$ showed about twice the binding capability of $\alpha$-lactalbumin with $\mathrm{OA}$. They reported that both $\mathrm{Lf}$ and OA were responsible for the antitumor activity of their complex, which was not the case with HAMLET that had an OA-dependent antitumor activity. In another study, two antitumor lactoferrin-OA and lactoferrin-linoleic acid complexes were successfully prepared, which displayed a perceptive prospect of cancer treatment (Zhang et al., 2015a).

In view of the established and significant association between lactoferrin and cancer and the previous studies confirming high OA/Lf-dependent antitumor activity of bLf-OA complex besides considering the problem of OA adverse effects on both cancer and normal cells, the present work studied the antitumor activity of formulated camel lactoferrin-OA (cLf-OA) and human lactoferrin-OA (hLf-OA) nanocomplexes.

\section{MATERIALS AND METHODS}

\section{Anticancer agents}

Used milk was collected and processed for camel lactoferrin (cLf) and human lactoferrin (hLf) purification. Both lactoferrins were purified from processed milk at our lab as formerly reported (Almahdy et al., 2011; El-Fakharany et al., 2013). The purified preparations of camel and human lactoferrins were filter sterilized via a syringe filter of $0.22 \mu \mathrm{m}$ pore size from TPP (St. Louis, MO) and then preserved in the freezer at $-20^{\circ} \mathrm{C}$. Cell culture-tested OA with purity of $\geq 99.0 \%$ was purchased from Sigma-Aldrich (St. Louis, MO).

\section{Determination of cLf and hLf activity}

The activity of lactoferrins was estimated as reported by Ye et al. (2000), with slight modifications. About $50 \mu \mathrm{l}$ of each lactoferrin were added to a mixture comprising $15 \mu \mathrm{l}$ Tris- $\mathrm{HCl}$ buffer at a concentration of $50 \mathrm{mM}$ and $\mathrm{pH} 8.0$ with $75 \mu$ l dihydronicotinamide-adenine-dinucleotide-phosphate at a concentration of $300 \mu \mathrm{M}$, nitroblue tetrazolium (NBT) at a concentration of 300 $\mu \mathrm{M}$, and phenazinmethosulfate at a concentration of $30 \mu \mathrm{M}$. The absorbance at $580 \mathrm{~nm}$ was recorded initially and after 5 minutes of reaction. The used positive control was L-ascorbic acid. The activity of lactoferrins was then calculated from a standard curve made by the use of a series of NBT standards. Lactoferrins activity was reported as international units per milligram of protein.

\section{Preparation of conventional lactoferrin-OA complexes}

Different concentrations of camel and human lactoferrins were prepared by dissolving inphosphate buffered saline (PBS) buffer (10 mM, pH 8.0). OA was mixed with each protein solution at 50 molar equivalents of $\mathrm{OA}$ to lactoferrin, then vortexed for 30 seconds using FINEVORTEX (FINEPCR, Gunposi, Korea) and incubated for 20 minutes at $45^{\circ} \mathrm{C}$ in MultiTemp III water bath (Pharmacia Biotech, Uppsala, Sweden). After removal of excess $\mathrm{OA}$ by centrifugation at $4^{\circ} \mathrm{C}$, the prepared complexes were ultrafiltrated by Centricon with a membrane of $3 \mathrm{kDa}$ cut-off (Merck, Darmstadt, Germany) (Uversky et al., 2017).

\section{Evaluation of $O A$ concentration in the prepared lactoferrin- OA complexes}

$\mathrm{OA}$ in the prepared lactoferrin- OA complexes was evaluated by Duncombe colorimetric method (Duncombe, 1963). In brief, the prepared protein-OA complexes were shaken with a solution of chloroform containing copper. According to this method, the estimation of copper in chloroform by use of a color developer (sodium diethylthiocarbamate) is equivalent to $\mathrm{OA}$ in the protein-OA complexes, since fatty acids like OA can form a complex with copper ions which is soluble in chloroform. A copper reagent was prepared by mixing $1 \mathrm{M}$ triethanolamine $(9$ volumes), $1 \mathrm{~N}$ acetic acid (1 volume), and 10\% (w/v) copper sulfate (10 volumes). The prepared protein-OA complexes $(500 \mu \mathrm{l})$ or standard OA $(500 \mu \mathrm{l})$ were vigorously shaken with about $2.5 \mathrm{ml}$ of the copper reagent using vortex mixer. Afterward, chloroform (5 $\mathrm{ml}$ ) was added and vigorously shaken for an additional 1 minute. Subsequently, $3 \mathrm{ml}$ of the lower (chloroform) layer was separated and mixed with $0.1 \%$ sodium diethylthiocarbamate dissolved in butanol at a volume of $500 \mu 1$. Finally, the absorbance of samples was measured at $440 \mathrm{~nm}$.

\section{Preparation of nanocomplexes}

The cLf/hLf-OA complex-loaded chitosan nanoparticles were formulated according to the ionic gelation protocol, as formerly reported by Anitha et al. (2011). Chitosan at a concentration of $2 \mathrm{mg} / \mathrm{ml}$ was prepared by dissolving in $0.1 \%$ aqueous acetic acid with stirring continuously. $\mathrm{pH}$ adjustment to 5.5 was carried out by $1 \mathrm{~N} \mathrm{NaOH}$ using Jenco pH meter (Jenco, San Bernardino, CA). The prepared cLf-OA and hLf-OA complexes at $1 \mathrm{mg} / \mathrm{ml}$ were added dropwise over the course of 1 hour to the chitosan solution. Dextran sodium sulfate at a concentration of $0.5 \mathrm{mg} / \mathrm{ml}$ was added dropwise to the above-mentioned solution as a cross-linker to obtain nanocomplexes. The nanoformulated $\mathrm{cLf} / \mathrm{hLf}-\mathrm{OA}$ complexes were precipitated by centrifugation twice at $12,000 \mathrm{rpm}$ and $4{ }^{\circ} \mathrm{C}$ for 40 minutes and the precipitates were suspended in PBS then freeze-dried.

\section{Characterization of nanoformulated $\mathrm{cLf} / \mathrm{hLf}-\mathrm{OA}$}

The protein content in the supernatant was determined as absorbance at $280 \mathrm{~nm}$. Loading capacity for cLf- or hLf-OA and encapsulation efficiency of nanoformulations were evaluated. The mean hydrodynamic size of the nanoformulations was assessed by the particle size analyzer Zetasizer Nano ZS (Malvern, UK).

\section{Detecting cytotoxic effect on normal and cancer cells}

The normal human lung fibroblast WI-38 cell line CCL75 (ATCC, Manassas, VA) was used to detect cytotoxicity of cLf, hLf, cLf-OA, hLf-OA, and their nanocomplexes, as well as OA. WI-38 cell line at a density of $1 \times 10^{4}$ cells per well was maintained in the Dulbecco's modified Eagle medium (DMEM) growth medium (Lonza, Verviers, Belgium) supplemented with $10 \%$ fetal bovine serum (FBS, Lonza) in a 96-well cell culture flat-bottom microplate (Greiner, Frickenhausen, Germany) and incubated at $37^{\circ} \mathrm{C}$ in $5 \% \mathrm{CO}_{2}$ incubator (BINDER, Tuttlingen, Germany). After cell attachment for 24 hours, WI-38 cells were 
treated with OA, cLf, hLf, their complexes, and nanocomplexes at serial concentrations and then incubated for 72 hours. The viability of cells was assessed by the MTT technique (El-Baky et al., 2011; Mosmann, 1983). Twenty microliters of MTT (Sigma) at a concentration of $5 \mathrm{mg} / \mathrm{ml}$ were added to each well, followed by incubation of the microplate at $37^{\circ} \mathrm{C}$ for 3 hours. The MTT solution was discarded, $100 \mu 1$ of dimethyl sulfoxide (DMSO) (Sigma) was then added, and the absorbance of the samples was measured at $570 \mathrm{~nm}$ using a microplate reader (BMG LabTech, Germany). The values of inhibitory concentrations $\left(\mathrm{IC}_{50}\right)$ (concentration achieving $50 \%$ cell viability) and concentration achieving $100 \%$ cell viability $\left(\mathrm{EC}_{100}\right)$ of OA, cLf, hLf, their complexes, and nanocomplexes were estimated with the Graphpad Instat software (Graphpad Software, San Diego, CA). This assay was repeated thrice, each in triplicate, and then the obtained results were expressed as mean \pm standard error of the mean (SEM).

The anticancer potential of OA, cLf, hLf, cLf-OA, hLf$\mathrm{OA}$, and their nanocomplexes was evaluated against four human tumor cells; liver tumor cell line HepG-2 HB-8065, cervical tumor cell line HelaCCL-2, colon tumor cell line Caco-2 HTB-37, and breast tumor cell line MCF-7 HTB-22 were obtained from ATCC (Manassas, VA). Hela, HepG-2, and MCF-7 were maintained in RPMI-1640 supplemented medium (Lonza), while Caco-2 cell line was cultured in a DMEM supplemented medium. Both media were supplemented with $10 \%$ FBS. All tested cancer cells were seeded into 96-well cell culture microplates at a density of $5 \times$ $10^{3}$ cells/well, and then left to attach for 24 hours. The four cancer cell lines were treated with OA, cLf, hLf, their complexes, and nanocomplexes at serial concentrations and then incubated at $37^{\circ} \mathrm{C}$ for 72 hours in $5 \% \mathrm{CO}_{2}$ incubator. MTT method was performed and $\mathrm{IC}_{50}$ values were calculated as described above.

Moreover, the morphological alterations in the test normal and cancer cells after 72 hours exposure to the tested samples were checked by a phase-contrast microscope (Olympus, Japan). These changes were compared to untreated cells.

\section{Apoptotic investigation for treated cancer cells using nuclear staining analysis}

cLf-OA and hLf-OA and their nanocomplexes were incubated for 72 hours with the cancer cell lines at their safe doses $\left(\mathrm{EC}_{100}\right)$. After that, cancer cells before and after treatment were stained with double nuclear stains of ethidium bromide and acridine orange (Sigma). Then, apoptosis was investigated in all tested cancer cells using the fluorescence phase-contrast microscope (Olympus) with an excitation filter (480/30 nm) and a dichromatic mirror, $505 \mathrm{~nm}$ cut-on.

Additionally, cell apoptosis was assessed by PI and annexin V staining (Sigma) and flow cytometry (PARTEC, Görlitz, Germany); cLf-OA, hLf-OA, and their nanocomplexes were incubated for 72 hours with the cancer cell lines at their $\mathrm{EC}_{100}$. After trypsinization, the cancer cells before and after treatment were stained for 15 minutes with annexin $\mathrm{V}$ and PI nuclear staining. Afterward, cells were fixed and incubated with 5 $\mu \mathrm{g} / \mathrm{ml}$ of streptavidine-fluorescein (Sigma) for 15 minutes. Flow cytometry was used to estimate cell death via quantification of both PI-stained necrotic cells and annexin-stained apoptotic cells.

These assays were repeated thrice in triplicate, and all the obtained results are presented as mean \pm SEM.

\section{Determining the increment in the reactive oxygen species (ROS) production in cancer cells after treatment}

For the detection of intracellular ROS level, $5 \mu \mathrm{M}$ of 2', $7^{\prime}$-dichlorodihydrofluorescein diacetate $\left(\mathrm{H}_{2} \mathrm{DCFDA}\right.$, Sigma) was incubated at $37^{\circ} \mathrm{C}$ for 30 minutes in the dark with cancer cells after and before treatment with either conventional or nanocomplexes. Then, cells were harvested with the Trypsin-ethylenediaminetetraacetic acid (EDTA) solution and suspended in fresh PBS. The percentage of oxidized fluorescence DCFDA was analyzed with a flow cytometer with excitation and emission settings at $488 \mathrm{~nm}$ and 530 $\mathrm{nm}$, respectively. This test was repeated thrice in triplicate and the obtained results are presented as mean \pm SEM.

\section{Immunocytochemical nuclear staining protocol for Ki-67, Bcl-2, and p53 IN HepG-2}

Following trypsinization, untreated in addition to treated HepG-2 were centrifuged and washed with PBS. Cell pellets were suspended in $10 \%$ formalin in PBS. The fixed cell specimens were dehydrated in ascending grades of alcohol. After immersing for 1 hour in xylene thrice, cells were impregnated in melted paraffin to produce solid paraffin blocks. Each paraffin block was cut into 3-5 $\mu \mathrm{m}$ thick sections using a rotator microtome; then, sections were transferred to positively charged slides. Slides were dried for $1-2$ hours at $60^{\circ} \mathrm{C}-70^{\circ} \mathrm{C}$ then dewaxed by immersion in xylene thrice. Subsequently, slides were rehydrated in descending grading ethanol and incubated in $3 \% \mathrm{H}_{2} \mathrm{O}_{2}$ for 10 minutes. After washing twice in PBS for 3 minutes, the slides were placed in $10 \mathrm{mM}$ citrate buffer, followed by heating for 10-20 minutes. After cooling and washing in PBS, the slides were separately soaked overnight in primary antibodies against Ki-67, Bcl-2, or p53. Slides were washed in PBS, covered with biotinylated goat anti-polyvalent secondary antibody for 10 minutes and then streptavidin-peroxidase was added for 10 minutes. The substrate 3, 3'-diaminobenzidine was added, followed by washing in PBS and placing for 1-4 minutes in hematoxylin bath then washing in PBS for 1 minutes and water for 3 minutes. The imaging analysis software CellSens of a phase-contrast microscope (Olympus) was used to determine the percentage of immunostained cells.

\section{RESULTS}

\section{Lactoferrins activity evaluation}

In the current study, the activity of both cLf and hLf was estimated by their ability to inhibit superoxide radical generation. Their mean activity was $6.79 \pm 2.31 \mathrm{U} / \mathrm{mg}$ of protein for hLf and $9.84 \pm 1.18 \mathrm{U} / \mathrm{mg}$ of protein for cLf.

\section{Estimation of $O A$ concentration in the prepared lactoferrin- OA complexes}

OA concentrations in the prepared $\mathrm{hLf}-\mathrm{OA}$ and $\mathrm{cLf}-\mathrm{OA}$ complexes were presented as mean $\pm \mathrm{SEM}$; for cLf-OA it was $0.241 \pm 0.02 \mathrm{mM}$ and for hLf-OA it was $0.376 \pm 0.017 \mathrm{mM}$.

\section{Characterization of nanoparticles' formulations for $\mathrm{cLf}-\mathrm{OA}$ and hLf-OA}

The nanoparticles formulations for $\mathrm{cLf}-\mathrm{OA}$ and $\mathrm{hLf}-$ OA were characterized with regard to loading capacity for cLf- or $\mathrm{hLf}-\mathrm{OA}$, encapsulation efficiency of nanoparticles, and the mean 
hydrodynamic size of the nanoparticles as presented in Table 1. Results presented in Table 1 reveal that the size of cLf-OA and $\mathrm{hLf}-\mathrm{OA}$ complexes had decreased from $16.04 \pm 0.85$ and $18.15 \pm$ $0.4 \mu \mathrm{m}$, respectively, to the nanoscale $(197.5 \pm 1$ and $199.6 \pm 1.4$ $\mathrm{nm}$, respectively) to achieve improvement in the release and safety of these complexes.

\section{Cytotoxic effect of cLf, hLf, OA, cLf-OA, hLf-OA, and their nanocomplexes on normal and tumor cells}

The cell viability of WI-38, Caco-2, HepG-2, Hela, and MCF-7 cells after treatment with cLf, hLf, OA, cLf-OA, hLf-OA, and their nanocomplexes for 72 hours was measured using the MTT method (Tables 2 and 3). The $\mathrm{IC}_{50}$ and $\mathrm{EC}_{100}$ values of cLf, hLf, cLf-OA, hLf-OA and their nanocomplexes against normal human WI-38 cell line, shown in Table 2, reveal that cLf-OA complex $\left(\mathrm{IC}_{50}\right.$ of $\left.88.18 \pm 1.22 \mu \mathrm{g} / \mathrm{ml}\right)$ and $\mathrm{hLf}-\mathrm{OA}$ complex $\left(\mathrm{IC}_{50}\right.$ of 91.52 $\pm 1.17 \mu \mathrm{g} / \mathrm{ml}$ ) have the highest inhibitory effect against normal cells, while cLf $\left(\mathrm{EC}_{100}\right.$ of $\left.425.23 \pm 2.63 \mu \mathrm{g} / \mathrm{ml}\right)$ and $\mathrm{hLf}\left(\mathrm{EC}_{100}\right.$ of $446.35 \pm 12.08 \mu \mathrm{g} / \mathrm{ml})$, followed by cLf-OA nanocomplex $\left(\mathrm{EC}_{100}\right.$ of $105.07 \pm 0.39 \mu \mathrm{g} / \mathrm{ml})$ and $\mathrm{hLf}-\mathrm{OA}$ nanocomplex $\left(\mathrm{EC}_{100}\right.$ of 111.7 $\pm 2 \mu \mathrm{g} / \mathrm{ml}$ ) have the least inhibitory effect on normal cells.
The $\mathrm{IC}_{50}$ values of $\mathrm{cLf}$ and $\mathrm{hLf}$ before and after combination with OA and nanoformulation against human cancer cell lines demonstrated in Table 3 reveal that cLf-OA and hLfOA complexes or nanocomplexes showed significantly $(p<0.05)$ higher anticancer activity than cLf and $\mathrm{hLf}$ before combination with OA. The antitumor activity of OA is shown in Table 3, where the $\mathrm{IC}_{50}$ values of OA are $1.103 \pm 0,0.599 \pm 0.11,1.983$ \pm 0.02 , and $0.445 \pm 0.04 \mathrm{mM}$ for HepG-2, Caco-2, Hela, and MCF-7, respectively. The actual concentration values of OA in the prepared complexes were $0.241 \pm 0.02 \mathrm{mM}$ for $\mathrm{cLf}-\mathrm{OA}$ and $0.376 \pm 0.017 \mathrm{mM}$ for hLf-OA, which were significantly $(p<$ $0.05)$ lower concentrations than the $\mathrm{IC}_{50}$ values against test cancer cells, thus the improvement in antitumor effect of cLf-OA and $\mathrm{hLf-OA}$ complexes or their nanoformulations was not a result of an elevated OA concentration in the prepared lactoferrin- OA conventional or nanocomplexes, but it established the fact that lactoferrin proteins participate in this improved antitumor effect of conventional and nanocomplexes.

The problem was that $\mathrm{IC}_{50}$ values of cLf-OA and hLfOA complexes against Caco- 2 and MCF-7 cells were significantly $(p<0.05)$ higher than their $\mathrm{EC}_{100}$ against normal WI-38 cells,

Table 1. Characterization of cLf-OA and hLf-OA nanocomplexes.

\begin{tabular}{cccc}
\hline Nanocomplex sample & Loading capacity $(\%)^{\mathbf{a}}$ & Encapsulation efficiency (\%) $^{\mathrm{b}}$ & Size $(\mathbf{n m})$ \\
\hline cLf-OA & $54.11 \pm 0.123$ & $86.57 \pm 0.197$ & $197.5 \pm 1$ \\
hLf-OA & $56.9 \pm 0.65$ & $91.05 \pm 1.05$ & $199.6 \pm 1.4$ \\
\hline
\end{tabular}

All values are expressed as mean \pm SEM.

Where A represents the total protein amount, $\mathrm{B}$ is the free protein amount in the supernatant, and $\mathrm{C}$ is the nanoformulation weight. a\% loading capacity $=[(\mathrm{A}-\mathrm{B}) / \mathrm{C}] \times 100$.

$\mathrm{b} \%$ encapsulation efficiency $=[(\mathrm{A}-\mathrm{B}) / \mathrm{A}] \times 100$

Table 2. The $\mathrm{IC}_{50}$ and $\mathrm{EC}_{100}$ values $(\mu \mathrm{g} / \mathrm{ml})$ of cLf, hLf, cLf-OA, and $\mathrm{hLf}-$ $\mathrm{OA}$ and their nanocomplexes against normal human WI-38 cell line.

\begin{tabular}{lcc}
\hline Sample & $\mathbf{I C}_{\mathbf{5 0}}(\boldsymbol{\mu \mathrm { g }} / \mathbf{\mathrm { ml } )}$ & $\mathbf{E C}_{\mathbf{1 0 0}}(\boldsymbol{\mu \mathrm { g }} / \mathbf{\mathrm { ml }})$ \\
\hline $\mathrm{cLf}$ & $834.92 \pm 8.7$ & $425.23 \pm 2.63$ \\
$\mathrm{hLf}$ & $898.46 \pm 6.63$ & $446.35 \pm 12.08$ \\
OA $(\mathrm{mM})$ & $0.0307 \pm 0$ & $0.0109 \pm 0$ \\
cLf-OA complex & $88.18 \pm 1.22$ & $43.27 \pm 2.11$ \\
hLf-OA complex & $91.52 \pm 1.17$ & $46.33 \pm 2.21$ \\
cLf-OA nanocomplex & $216.15 \pm 1.19$ & $105.07 \pm 0.39$ \\
hLf-OA nanocomplex & $218.8 \pm 8.82$ & $111.7 \pm 2$ \\
\hline
\end{tabular}

Data are presented as mean $\pm \mathrm{SEM}$.

Table 3. The $\mathrm{IC}_{50}$ values $(\mu \mathrm{g} / \mathrm{ml})$ of cLf, hLf, cLf-OA, and $\mathrm{hLf}-\mathrm{OA}$ and their nanocomplexes against human tumor cells.

\begin{tabular}{lcccc}
\hline Sample & HepG-2 & Caco-2 & Hela & MCF-7 \\
\hline cLf & $1,011.4 \pm 3.4$ & $2,127.4 \pm 15.08$ & $1,352.9 \pm 22.5$ & $1,229.2 \pm 15.63$ \\
hLf & $666.36 \pm 11.8$ & $2,072.9 \pm 5.33$ & $1,139.3 \pm 8.4$ & $1,175.7 \pm 14.62$ \\
OA (mM) & $1.103 \pm 0$ & $0.599 \pm 0.11$ & $1.983 \pm 0.02$ & $0.445 \pm 0.04$ \\
cLf-OA complex & $29.42 \pm 0.72$ & $55.69 \pm 0.38$ & $34.15 \pm 0.32$ & $80.19 \pm 0.04$ \\
hLf-OA complex & $28.46 \pm 0.86$ & $49.99 \pm 0.07$ & $29.88 \pm 0.07$ & $78.30 \pm 0.44$ \\
cLf-OA nanocomplex & $36.48 \pm 1.25$ & $85.12 \pm 0.15$ & $55.09 \pm 0.67$ & $82.61 \pm 0.2$ \\
hLf-OA nanocomplex & $33.64 \pm 2.25$ & $66.64 \pm 5.57$ & $47.09 \pm 0.99$ & $78.73 \pm 0.22$ \\
\hline
\end{tabular}

Data are presented as mean \pm SEM. 
indicating that they could not be selective in killing tumor cells. On the contrary, all $\mathrm{IC}_{50}$ values of cLf-OA and hLf-OA nanocomplexes against HepG-2, Caco-2, Hela, and MCF-7 cells were significantly $(p<0.05)$ lower than their $\mathrm{EC}_{100}$ against normal WI-38 cells, indicating their selectively in killing tumor cells.

The morphological alterations in the test normal and cancer cells after 72 hours exposure to the tested samples under a phase-contrast microscope are shown in Figures 1 and 2.

\section{Apoptotic investigation for treated cancer cells using nuclear staining analysis}

The results of the acridine orange and ethidium bromide staining for detecting cancer cell apoptosis by a fluorescence phasecontrast microscope are shown in Figure 3. The nanoparticles formulations for $\mathrm{cLf}-\mathrm{OA}$ and $\mathrm{hLf}-\mathrm{OA}$ induced apoptosis in test tumor cells after 72 hours exposure to their $\mathrm{EC}_{100}$, in a more notably effective manner than $\mathrm{cLf}-\mathrm{OA}$ and $\mathrm{hLf}-\mathrm{OA}$ complexes.

Additional evidence for inducing apoptosis in test tumor cells by cLf-OA, hLf-OA, and their nanoparticles formulations was achieved using annexin $\mathrm{V}$ and PI staining protocols and flow cytometry (Fig. 4). At their $\mathrm{EC}_{100}, \mathrm{cLf}-\mathrm{OA}$ and hLf-OA induced apoptosis in $50.24 \% \pm 0.09 \%$ and $52.71 \% \pm 0.74 \%$, respectively, of HepG-2 compared to $5.18 \% \pm 0.16 \%$ in untreated cells, $31.57 \% \pm 0.46 \%$ and $34.3 \% \pm 0.69 \%$, respectively, of Caco- 2 compared to $0.065 \pm 0.005$ in untreated cells, $41.23 \% \pm 0.79 \%$ and $46.15 \% \pm 1.04 \%$, respectively, of Hela compared to 0.035 \pm 0.005 in untreated cells, and $24.99 \% \pm 0.98 \%$ and $29.19 \% \pm$ $0.44 \%$, respectively, of MCF-7 total cells compared to $5.35 \pm 0.16$ in untreated cells. On the other hand, nanoparticles formulations of cLf-OA and hLf-OA induced apoptosis in $67.83 \% \pm 0.24 \%$ and $69.19 \% \pm 0.17 \%$, respectively, of HepG- $2,45.34 \% \pm 0.73 \%$ and $50.58 \% \pm 0.56 \%$, respectively, of Caco-2, $52.25 \% \pm 1.22 \%$ and $55.01 \% \pm 0.72 \%$, respectively, of Hela, and $44.14 \% \pm 0.51 \%$ and $47.37 \% \pm 0.82 \%$, respectively, of MCF-7 total cells. Almost no apoptotic cells were detected in untreated test cancer cells $(5.18 \%$ $\pm 0.16 \%, 0.065 \% \pm 0.005 \%, 0.035 \% \pm 0.005 \%, 5.35 \% \pm 0.16 \%$ in HepG-2, Caco-2, Hela, and MCF-7, respectively).

\section{Determining the increment in the ROS production in treated cancer cells}

The results of the flow cytometric analysis of oxidized DCFDA in HepG-2, Caco-2, Hela, and MCF-7 after 72 hours incubation with $\mathrm{EC}_{100}$ of cLf-OA, hLf-OA, cLf-OA nanocomplex, and hLf-OA nanocomplex are shown in Figure 5. cLf-OA, hLfOA, cLf-OA nanocomplex, and hLf-OA nanocomplex produced oxidized DCFDA of $82.43 \% \pm 0.37 \%, 82.55 \% \pm 0.31 \%, 88.47 \%$ $\pm 0.36 \%$, and $89.56 \% \pm 0.06 \%$, respectively, in HepG-2, $38.65 \%$ $\pm 0.12 \%, 48.74 \% \pm 0.72 \%, 74.03 \% \pm 0.8 \%$, and $78.55 \pm 0.14$, respectively, in Caco-2, 61.7\% $\pm 1.13 \%, 64.03 \% \pm 2.4 \%, 76.77 \%$ $\pm 0.79 \%$, and $79.44 \pm 1.35$, respectively, in Hela, and $11.47 \%$ $\pm 0.95 \%, 15.78 \% \pm 0.29 \%, 69.2 \% \pm 0.44 \%$, and $75.94 \pm 0.74$, respectively, in MCF-7. These results suggest that cLf-OA and $\mathrm{hLf}-\mathrm{OA}$ and their nanoformulations result in a significant $(p<$ $0.05)$ increase in ROS of test tumor cells, but this increase was higher in case of nanocomplexes. The increment of the generated oxidized DCFDA is a sign for alteration of cellular redox state of treated cancer cells to be more oxidized then apoptosis is induced by a higher extent.

\section{Immunocytochemical evaluation of Ki-67, Bcl-2, and p53 Levels in HepG-2 cells treated with nanocomplexes}

The level of markers of apoptosis (apoptosis inhibiting Bcl-2 and tumor suppressor protein p53) and cellular proliferation (Ki-67) was evaluated in HepG-2 treated with nanocomplexes, as shown in Figure 6. Percentage values (values were expressed as mean \pm SEM) of ki-67-stained cells, Bcl-2-stained cells, and p53stained cells in untreated control HepG-2 were $95.93 \% \pm 0.93 \%$, $93.49 \% \pm 0.5 \%$, and $2.98 \% \pm 0.11 \%$, respectively. HepG- 2 cells

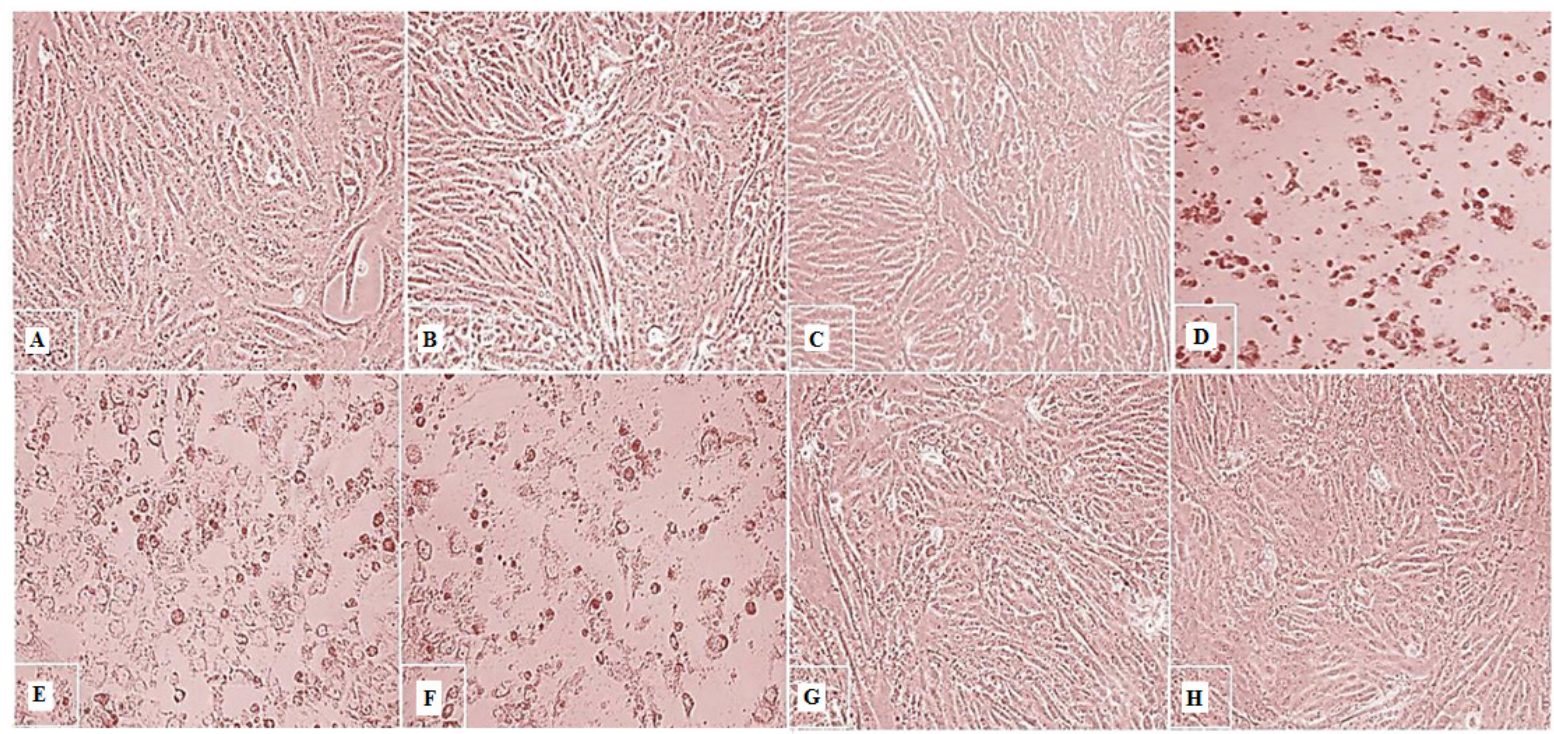

Figure 1. Morphological alterations of WI-38 cell line under phase-contrast microscope with 200× magnification. (A) Untreated cells, (B) cells treated with $100 \mu \mathrm{g} / \mathrm{ml}$ of cLf for 72 hours, (C) cells treated with $100 \mu \mathrm{g} / \mathrm{ml}$ of hLf for 72 hours, (D) cells treated with $0.1 \mathrm{mM} \mathrm{OA}$ for 72 hours, (E) cells treated with $100 \mu \mathrm{g} / \mathrm{ml}$ of cLf-OA complex for 72 hours, (F) cells treated with $100 \mu \mathrm{g} / \mathrm{ml}$ of hLf-OA complex for 72 hours, (G) cells treated with $100 \mu \mathrm{g} / \mathrm{ml}$ of cLf-OA nanocomplex for 72 hours, and (H) cells treated with $100 \mu \mathrm{g} / \mathrm{ml}$ of hLf-OA nanocomplex for $72 \mathrm{~h}$. 


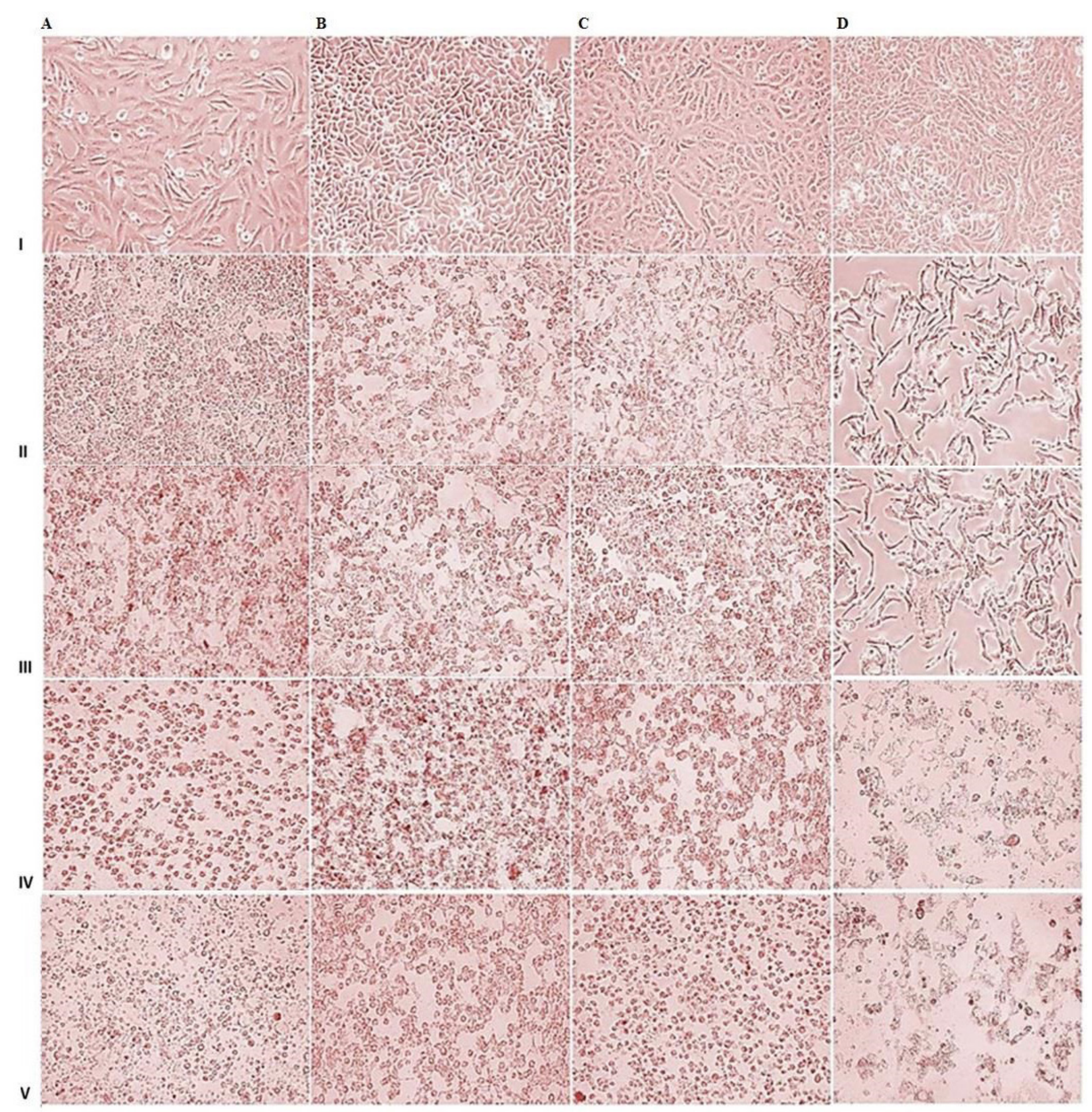

Figure 2. Morphological alterations of HepG-2 (A), Caco-2 (B), Hela(C), and MCF-7 (D) under phase-contrast microscope with 200× magnification. (I) Untreated cells, (II) cells treated with $\mathrm{EC}_{100}$ of cLf-OA complex for 72 hours, (III) cells treated with $\mathrm{EC}_{100}$ of $\mathrm{hLf}-\mathrm{OA}$ complex for 72 hours, (IV) cells treated with $\mathrm{EC}_{100}$ of cLf-OA nanocomplex for 72 hours, and (V) cells treated with $\mathrm{EC}_{100}$ of hLf-OA nanocomplex for 72 hours.

treated with cLf-OA and hLf-OA nanocomplexes demonstrated percentage values of ki-67-stained cells, Bcl-2-stained cells, and p53-stained of $29.45 \% \pm 1.47 \%$ and $26.61 \% \pm 1.38 \%, 25.071 \% \pm$ $1.19 \%$ and $23.39 \% \pm 1.46 \%, 69.08 \% \pm 1.11 \%$ and $71 \% \pm 0.96 \%$, respectively.

\section{DISCUSSION}

OA has antitumor activity against various carcinoma cells because of its ability to disturb the structure of biological membranes and thus membrane-bound proteins' function (Amara, 2013, 2015). Many studies confirmed in vitro anticancer effect of bLf on various tumor cells (Amiri et al., 2015; Zhang et al., 2015b).
Previous studies found that bLf could bind OA to kill cancer cells and that the resulting complex has a much higher anticancer activity than HAMLET (Fang et al., 2014; Zhang et al., 2015a). We previously focused on evaluating antibacterial (Almehdar et al., 2019, 2020; Redwan et al., 2016) and anti-hepatitis C virus (ElBaky et al., 2017; El-Fakharany et al., 2008; El-Fakharany et al., 2013; Liao et al., 2012; Redwan and Tabll, 2007) activities of cLf and confirmed that $\mathrm{cLf}$ was the most active lactoferrin among the different species studied. Moreover, the complex consisting of OA and camel $\alpha$-lactalbumin was previously proven to be an effective and promising anticancer entity, and formulated OA-camel protein complexes were considered a potential approach for cancer therapy 


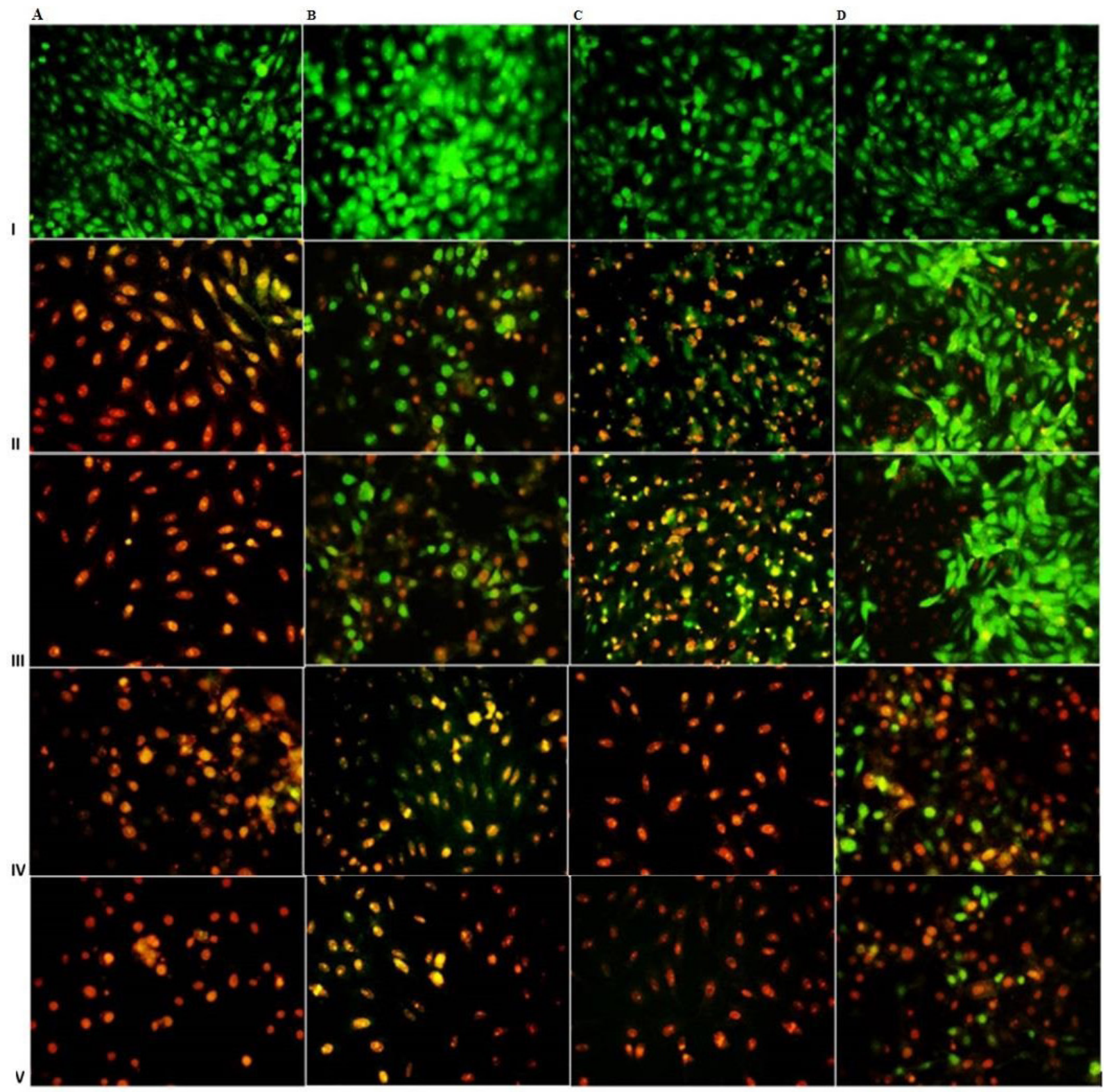

Figure 3. Fluorescence photomicrographs of HepG-2 (A), Caco-2 (B), Hela (C), and MCF-7 (D). (I) Untreated cells, (II) cells treated with $\mathrm{EC}_{100}$ of cLf-OA complex for 72 hours, (III) cells treated with $\mathrm{EC}_{100}$ of hLf-OA complex for 72 hours, (IV) cells treated with $\mathrm{EC}_{100}$ of cLf-OA nanocomplex for 72 hours, and (V) cells treated with $\mathrm{EC}_{100}$ of hLf-OA nanocomplex for 72 hours. Green, orange, and red fluorescence refer to normal cells, early apoptotic cells, and late apoptotic cells, respectively.

(Uversky et al., 2017), decreasing the size of a drug to nanoscale results in improvement in the drug release, delivery, and safety (Alishahi and Elsabee, 2011; Khan et al., 2019). Nanoparticles formulations of lactoferrin were previously prepared and were proved to have enhanced therapeutic efficacy (Kanwar et al., 2012; Kumari and Kondapi, 2017; Tomitaka et al., 2015).

In this work, we formulated cLf-OA and hLf-OA complex-loaded chitosan nanoparticles that achieved elevated cLf/hLf- and OA-dependent cytotoxicity to different cancer cells while sparing normal healthy cells. It was observed that the $\mathrm{IC}_{50}$ values of $\mathrm{OA}$ were $1.103 \pm 0,0.599 \pm 0.11,1.983 \pm 0.02$, and 0.445 $\pm 0.04 \mathrm{mM}$ for HepG-2, Caco-2, Hela, and MCF-7, respectively. On the other hand, the $\mathrm{IC}_{50}$ and $\mathrm{EC}_{100}$ values of OA were 0.0307 \pm 0 and $0.0109 \pm 0 \mathrm{mM}$, respectively against WI-38 cells. Based on these data and the concentration values of OA in the prepared complexes measured as $0.241 \pm 0.02 \mathrm{mM}$ for cLf-OA and $0.376 \pm$ $0.017 \mathrm{mM}$ for hLf-OA, it could be concluded that OA caused cLfOA complex $\left(\mathrm{IC}_{50}\right.$ of $\left.88.18 \pm 1.22 \mu \mathrm{g} / \mathrm{ml}\right)$ and $\mathrm{hLf}-\mathrm{OA}$ complex $\left(\mathrm{IC}_{50}\right.$ of $\left.91.52 \pm 1.17 \mu \mathrm{g} / \mathrm{ml}\right)$ to have the highest inhibitory effect against normal cells. Moreover, $\mathrm{IC}_{50}$ values of $\mathrm{cLf}-\mathrm{OA}$ and $\mathrm{hLf}-$ OA complexes against Caco- 2 and MCF-7 cells were significantly $(p<0.05)$ higher than their $\mathrm{EC}_{100}$ against normal WI-38 cells, indicating that they could not be selective in killing tumor cells. The nanoformulations for the two complexes achieved enhanced anticancer efficacy against test cancer cells and improved safety to normal cells. 


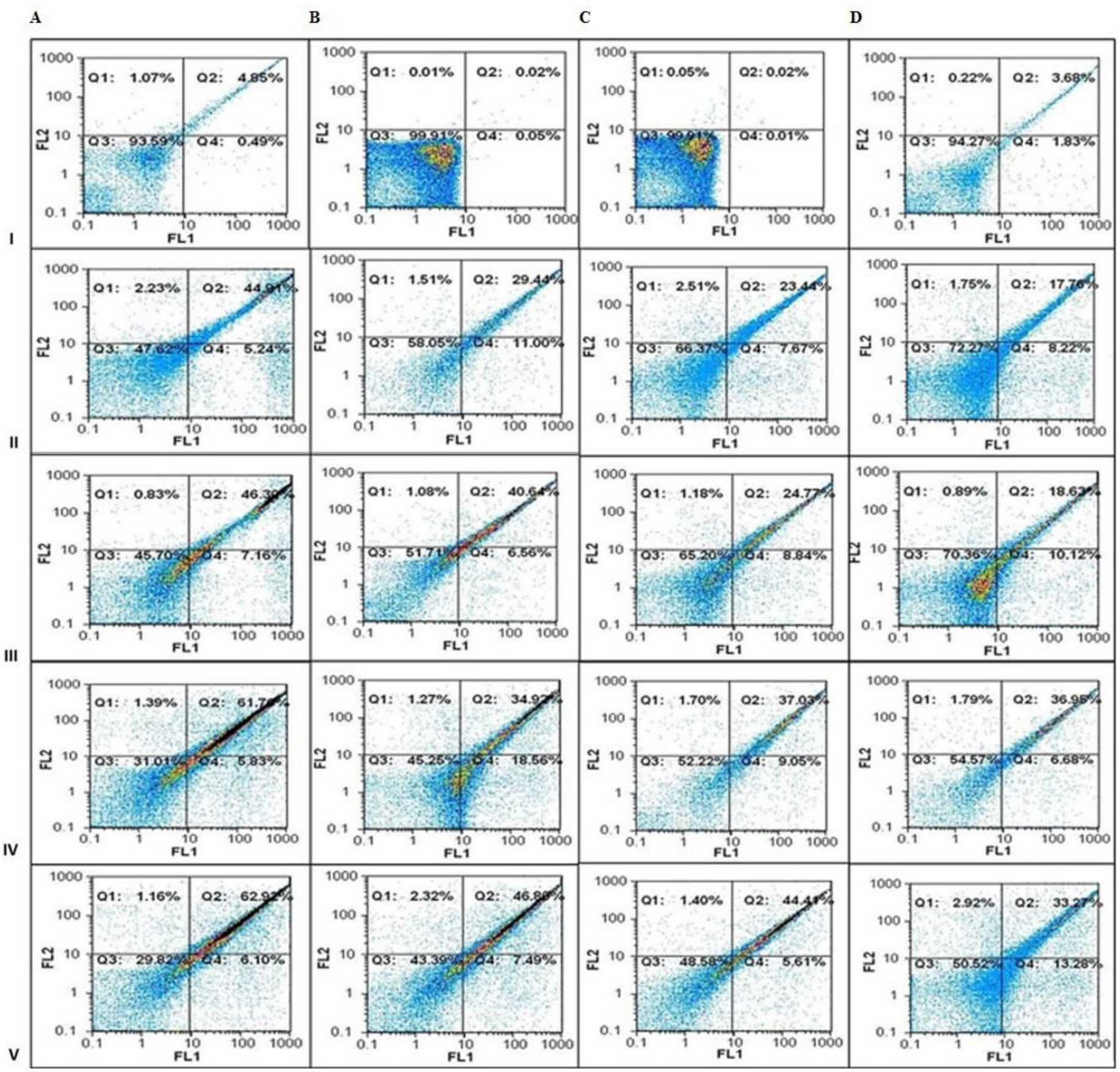

Figure 4. Flow cytometric analysis of cell death for HepG-2 (A), Caco-2 (B), Hela (C), and MCF-7 (D). (I) Untreated cells, (II) cells incubated with EC ${ }_{100}$ of cLf-OA complex for 72 hours, (III) cells incubated with $\mathrm{EC}_{100}$ of hLf-OA complex for 72 hours, (IV) cells incubated with $\mathrm{EC}_{100}$ of cLf-OA nanocomplex for 72 hours, and (V) cells incubated with $\mathrm{EC}_{100}$ of hLf-OA nanocomplex for 72 hours.

The concentrations of $\mathrm{OA}$ in the prepared lactoferrinOA complexes were found to be significantly $(p<0.05)$ lower than all of its $\mathrm{IC}_{50}$ values against test cancer cells. These results are in agreement with those described by Fang et al. (2014), who demonstrated that the improvement in antitumor effect of cLf$\mathrm{OA}$ and $\mathrm{hLf}-\mathrm{OA}$ complexes or their nanoformulations was not a result of an elevated OA concentration in the prepared lactoferrinOA conventional or nanocomplexes but established the fact that lactoferrin proteins also participate in this improved antitumor effect of conventional and nanocomplexes.
The results of the acridine orange, ethidium bromide, annexin V, and PI staining protocols and flow cytometry revealed that $\mathrm{cLf}-\mathrm{OA}$ and $\mathrm{hLf}-\mathrm{OA}$ nanocomplexes induced apoptosis in test tumor cells in a more notably effective manner than cLf-OA and hLf-OA conventional complexes. Additionally, a significant $(p<0.05)$ increase was found in ROS of test cancer cells after treatment with cLf-OA and hLf-OA and their nanocomplexes, but this increase was higher in case of nanocomplexes. Recently, a study reported that lactoferrin causes an increasing in the level of ROS of cancer cells (Zalutski et al., 2017) in addition to the 
A

B

C

D

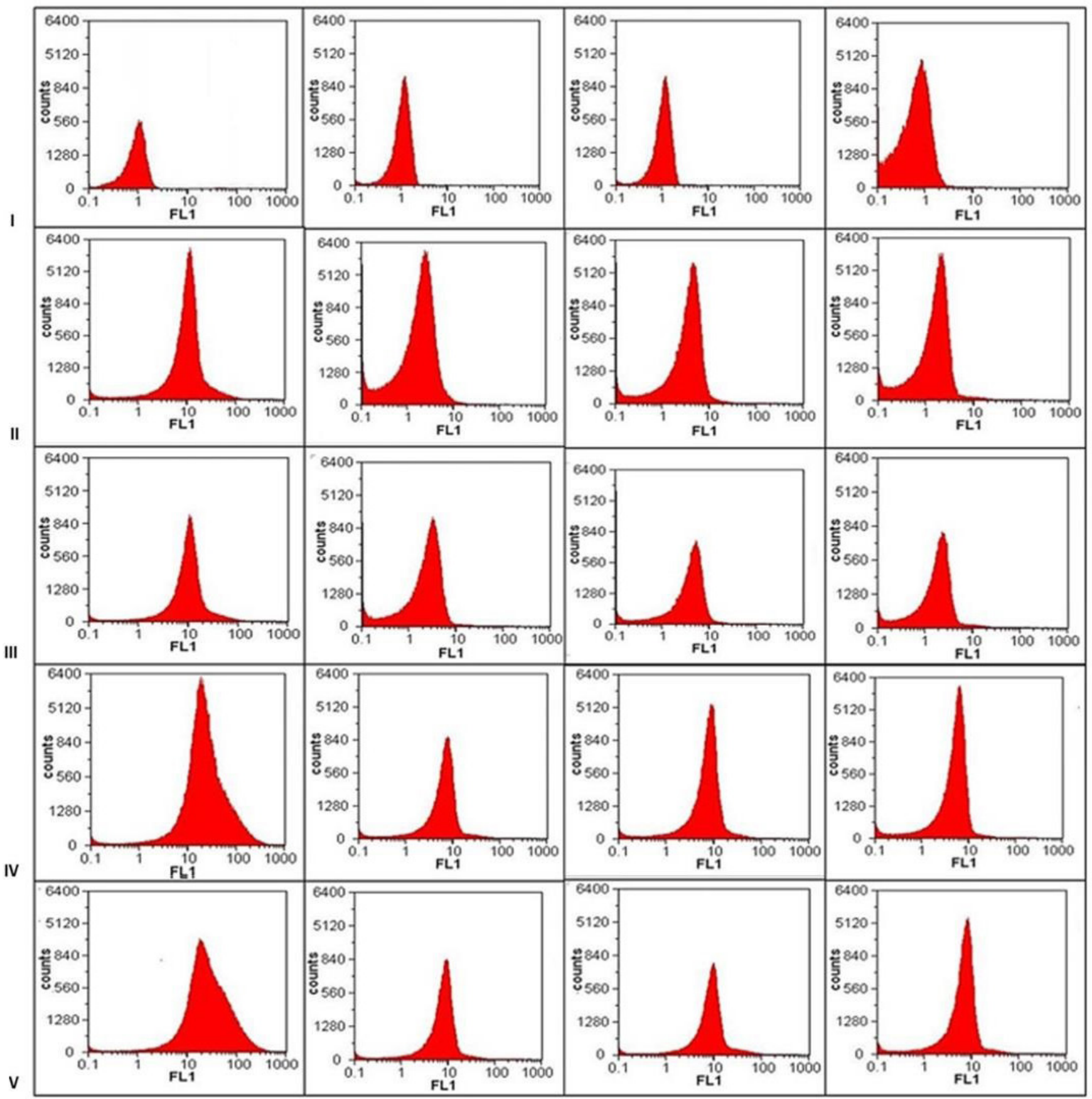

Figure 5. Flow cytometric analysis of oxidized DCFDA in HepG-2 (A), Caco-2 (B), Hela (C), and MCF-7 (D). (I) Untreated cells, (II) cells incubated with $\mathrm{EC}_{100}$ of cLf-OA complex for 72 hours, (III) cells incubated with $\mathrm{EC}_{100}$ of $\mathrm{hLf}-\mathrm{OA}$ complex for $72 \mathrm{hours}$, (IV) cells incubated with EC ${ }_{100}$ of cLf-OA nanocomplex for 72 hours, and (V) cells incubated with $\mathrm{EC}_{100}$ of $\mathrm{hLf}-\mathrm{OA}$ nanocomplex for 72 hours.

increase in ROS production caused by OA (Hatanaka et al., 2013). Our results show that cLf-OA and hLf-OA and their nanocomplexes induced apoptotic cell death in all tested cancer cells via the intrinsic pathway by the generation of ROS.

Alterations in the levels of $\mathrm{Ki}-67, \mathrm{Bcl}-2$, and $\mathrm{p} 53$ in response to treatment of HepG-2 cells with cLf-OA and hLfOA nanocomplexes were immunocytochemically analyzed using antibodies which recognized these proteins and found a significant decrease in levels of Ki-67 and Bcl-2, while the level of p53 was elevated. Thus, the cell apoptosis induced by $\mathrm{cLf}-\mathrm{OA}$ and $\mathrm{hLf}-\mathrm{OA}$ nanocomplexes involved the activation of the $\mathrm{p} 53 / \mathrm{Bcl} 2$ pathway. These results present our nanoformulations as a promising therapy for cancer.

The nanoformulation of lactoferrin was previously confirmed to possess stable activities when compared with those of free protein at $4^{\circ} \mathrm{C}$ for 9 weeks (Abu-Serie and El-Fakharany, 2017). 


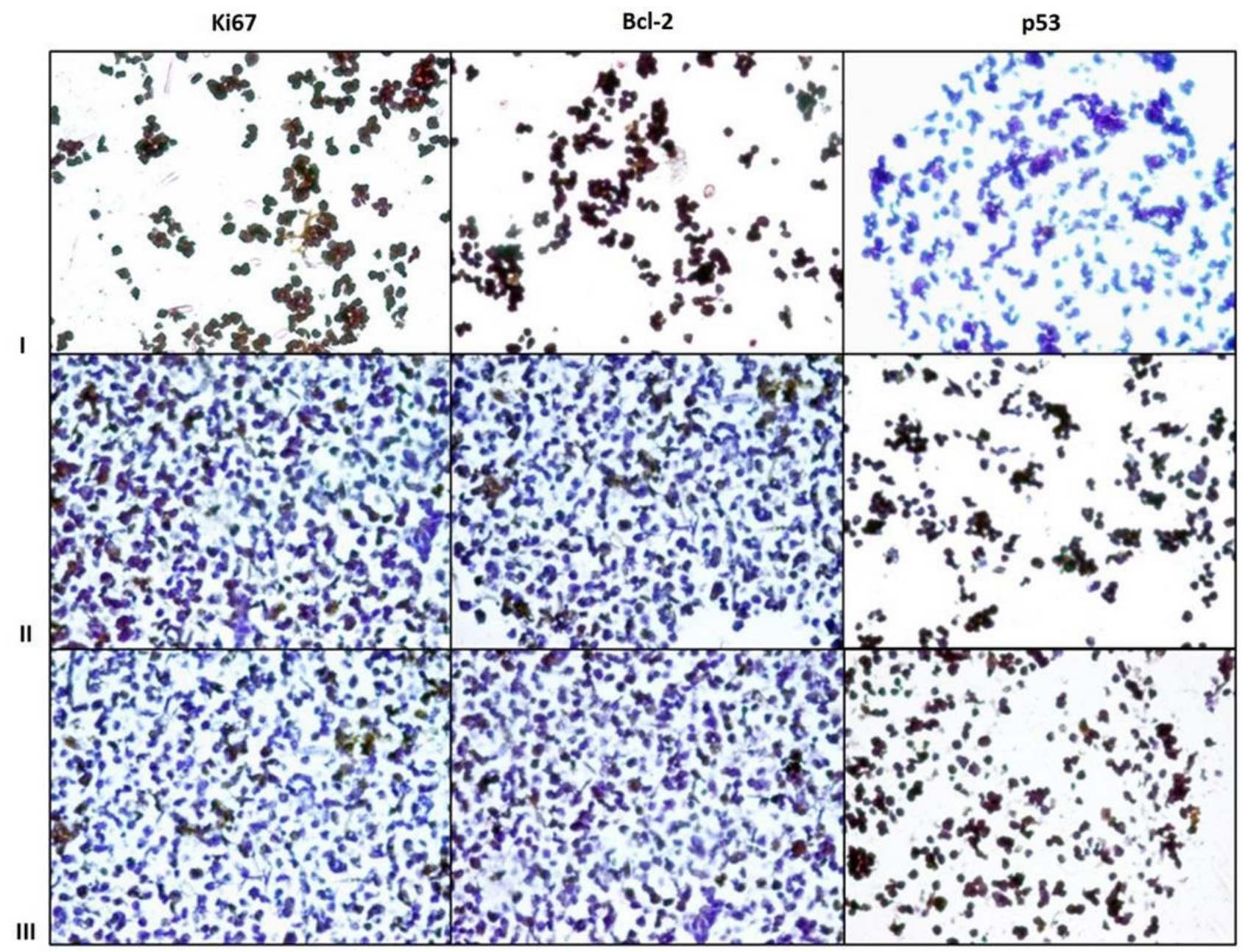

Figure 6. Immunocytochemistry analysis for Ki-67, Bcl-2, and p53 of HepG-2. (I) Untreated cells, (II) cells treated with cLf-OA nanocomplex, and (III) cells treated with hLf-OA nanocomplex.

\section{CONCLUSION}

The nanoformulations for $\mathrm{cLf}-\mathrm{OA}$ and $\mathrm{hLf}-\mathrm{OA}$ complexes achieved enhanced anticancer efficacy than free lactoferrin, free $\mathrm{OA}$, or even their complexes against test cancer cells and improved safety to normal cells because of their slow release. These nanocomplexes exhibited their potent apoptosisdependent anticancer effect via ROS upregulation, p53 stimulation, and Bcl-2 inhibition. Therefore, the prepared formulations can be considered a powerful candidate for cancer treatment.

\section{ABBREVIATIONS}

$\mathrm{bLf}=$ bovine lactoferrin; $\mathrm{cLf}=$ camel lactoferrin; DMSO $=$ dimethyl sulfoxide; $\mathrm{EC}_{100}$ the concentration of an agent that causes $100 \%$ cell viability; HAMLET $=$ complex of human $\alpha$-lactalbumin and oleic acid; $\mathrm{IC}_{50}$ the concentration of an agent that causes $50 \%$ cell viability; MTT $=3$-(4,5-dimethylthiazol2-yl)-2,5-diphenyltetrazolium bromide; OA = oleic acid; PI = propidium iodide; $\mathrm{SEM}=$ standard error of the mean.

\section{AUTHORS' CONTRIBUTIONS}

N. A. E.-B., M. M. A. S., and E. M. R. conceived the idea. N. A. E. B. and M. M. A. S., conducted the biological experiments, prepared figures, and wrote the manuscript. E. M. R. reviewed and finalized the manuscript. All authors read and approved the final manuscript.

\section{CONFLICT OF INTEREST}

The authors declare that they have no competing interests.

\section{ETHICS APPROVAL AND CONSENT TO PARTICIPATE} Not applicable.

\section{FUNDING}

None.

\section{AVAILABILITY OF DATA AND MATERIALS}

All data generated or analyzed during this study are included in this published article.

\section{REFERENCES}

Abu-Serie MM, El-Fakharany EM. Efficiency of novel nanocombinations of bovine milk proteins (lactoperoxidase and lactoferrin) for combating different human cancer cell lines. Sci Rep, $2017 ; 7: 16769$. 
Alishahi A, Elsabee AZ. Shelf life and delivery enhancement of vitamin C using chitosan nanoparticles. Food Chem, 2011; 126(3): $935-40$

Almahdy O, EL-Fakharany EM, EL-Dabaa E, Ng TB, Redwan EM. Examination of the activity of camel milk casein against hepatitis $\mathrm{C}$ virus (genotype-4a) and its apoptotic potential in hepatoma and Hela cell lines. Hepat Mon, 2011; 11(9):724-30.

Almehdar HA, El-Baky NA, Alhaider AA, Almuhaideb SA, Alhaider AA, Albiheyri RS, Uversky VN, Redwan EM. Bacteriostatic and bactericidal activities of camel lactoferrins against Salmonella entericaSerovar Typhi. Probiotics Antimicrob Proteins, 2020; 12(1):18-31.

Almehdar HA, El-Baky NA, Alhaider AA, Almuhaideb SA, Alhaider AA, Albiheyri RS, Uversky VN, Redwan EM. Synergistic killing of pathogenic Escherichia coli using camel lactoferrin from different Saudi camel clans and various antibiotics. Protein J, 2019; 38(4):479-96.

Amara AAAF. An overview of the molecular and cellular interactions of some bioactive compounds. In: Gupta VK, Tuohy MG (eds.). Biotechnology of bioactive compounds: sources and applications. John Wiley \& Sons, Ltd, Hoboken, NJ, pp 525-54, 2015.

Amara AAAF. The inevitability of balanced lives: genes and, foods in action and, interactions. IIOAB J, 2013; 4(2): 1-27.

Amiri F, Moradian F, Rafiei A. Anticancer effect of lactoferrin on gastric cancer cell line AGS. Res Mol Med, 2015; 3(2):11-6.

Anitha A, Gopal DV, Bijukumar D, Menon D, Nair S, Rangasamy J. Preparation, characterization, in vitro drug release and biological studies of curcumin loaded dextran sulphate-chitosan nanoparticles. Carbohydr Polym, 2011; 84(3):1158-64.

Duncombe WG. The colorimetric micro-determination of longchain fatty acids. Biochem J, 1963; 88(1):7-10.

El-Baky NA, El-Fakharany EM, Redwana EM. Lactoferrin and hepatitis $\mathrm{C}$ virus: flexible fitting and invasive mechanism. In: $\mathrm{Ng} \mathrm{TB}$, Wong JH, Tse R, Tse TG, Chan H (eds.). Lactoferrin: structure, biological functions, health benefits and clinical applications. Nova Science Publishers, Inc, New York, NY, pp 49-71, 2017.

El-Baky NA, Omar SH, Redwan EM. The anti-cancer activity of human consensus interferon-alpha synthesized in cell-free system. Protein Expr Purif, 2011; 80(1):61-7.

El-Fakharany EM, Sánchez L, Al-Mehdar HA, Redwan EM. Effectiveness of human, camel, bovine and sheep lactoferrin on the hepatitis C virus cellular infectivity: comparison study. Virol J, 2013; 10:199.

El-Fakharany EM, Tabll A, El-Wahab AA, Haroun BM, Redwan EM. Potential activity of camel milk-amylase and lactoferrin against hepatitis $\mathrm{C}$ virus infectivity in HepG2 and lymphocytes. Hepat Mon, 2008; 8(2):101-9.

Fang B, Zhang M, Tian M, Jiang L, Guo HY, Ren FZ. Bovine lactoferrin binds oleic acid to form an anti-tumor complex similar to HAMLET. Biochim Biophys Acta, 2014; 1841(4):535-43.

Furmanski P, Li Z, Fortuna MB, Swamy C, Das MR. Multiple molecular forms of human lactoferrin. Identification of a class of lactoferrins that possess ribonuclease activity and lack iron-binding capacity. J Exp Med, 1989; 170(2):415-29.

Hatanaka E, Dermargos A, Hirata AE, Vinolo MAR, Carpinelli A, Newsholme P, Armelin HA, Curi R. Oleic, linoleic and linolenic acids increase ROS production by fibroblasts via NADPH oxidase activation. PLoS One, 2013; 8(4):e58626.

Kanwar JR, Samarasinghe RM, Sehgal R, Kanwar RK. Nanolactoferrin in diagnostic, imaging and targeted delivery for cancer and infectious diseases. J Cancer Sci Ther, 2012; 4(3):031-42.

Khan I, Saeed K, Khan I. Nanoparticles: properties, applications and toxicities. Arab J Chem, 2019; 12(7):908-31.

Kumari S, Kondapi AK. Lactoferrin nanoparticle mediated targeted delivery of 5-fluorouracil for enhanced therapeutic efficacy. Int $\mathrm{J}$ Biol Macromol, 2017; 95:232-7.
Liao Y, El-Fakharany E, Lönnerdal B, Redwan EM. Inhibitory effects of native and recombinant full-length camel lactoferrin and its $\mathrm{N}$ and $\mathrm{C}$ lobes on hepatitis $\mathrm{C}$ virus infection of Huh7.5 cells. J Med Microbiol, 2012; 61(Pt 3):375-83.

Matsuda Y, Saoo K, Hosokawa K, Yamakawa K, Yokohira M, Zeng Y, Takeuchi H, Imaida K. Post-initiation chemopreventive effects of dietary bovine lactoferrin on 4-(methylnitrosamino)-1-(3-pyridyl)-1butanone-induced lung tumorigenesis in female A/J mice. Cancer Lett, 2006; 246(1-2):41-6.

Mosmann T. Rapid colorimetric assay for cellular growth and survival: application to proliferation and cytotoxicity assays. J Immunol Methods, 1983; 65(1-2):55-63.

Pan Y, Rowney M, Guo P, Hobman P. Biological properties of Lf: an overview. Aust J Dairy Technol, 2007; 62:31-42.

Redwan el-RM, Tabll A. Camel lactoferrin markedly inhibits hepatitis $\mathrm{C}$ virus genotype 4 infection of human peripheral blood leukocytes. J Immunoassay Immunochem, 2007; 28(3):267-77.

Redwan EM, El-Baky NA, Al-Hejin AM, Baeshen MN, Almehdar HA, Elsaway A, Gomaa AM, Al-Masaudi SB, Al-Fassi FA, AbuZeid IE, Uversky VN. Significant antibacterial activity and synergistic effects of camel lactoferrin with antibiotics against methicillin-resistant Staphylococcus aureus (MRSA). Res Microbiol, 2016; 167(6):480-91.

Tomitaka A, Arami H, Gandhi S, Krishnan KM. Lactoferrin conjugated iron oxide nanoparticles for targeting brain glioma cells in magnetic particle imaging. Nanoscale, 2015; 7(40):16890-8.

Tsuda H, Sekine K, Fujita K, Iigo M. Cancer prevention by bovine lactoferrin and underlying mechanisms - a review of experimental and clinical studies. Biochem Cell Biol, 2002; 80(1):131-6.

Uversky VN, El-Fakharany EM, Abu-Serie MM, Almehdar HA, Redwan EM. Divergent anticancer activity of free and formulated camel milk $\alpha$-Lactalbumin. Cancer Invest, 2017; 35(9):610-23.

Ward PP, Uribe-Luna S, Conneely OM. Lf and host defense. Biochem Cell Biol, 2002; 80(1):95-102.

Xu X, Jiang H, Li H, Zhang T, Zhou Q, Liu N. Apoptosis of stomach cancer cell SGC-7901 and regulation of Akt signaling way induced by bovine lactoferrin. J Dairy Sci, 2010; 93(6):2344-50.

Yamada Y, Sato R, Kobayashi S, Hankanga C, Inanami O, Kuwabara M, Momota Y, Tomizawa N, Yasuda J. The antiproliferative effect of bovine lactoferrin on canine mammary gland tumor cells. J Vet Med Sci, 2008; 70(5):443-8.

Ye X, Wang H, Liu F, Ng T. Ribonuclease, cell-free translationinhibitory and superoxide radical scavenging activities of the iron-binding protein lactoferrin from bovine milk. Int J Biochem Cell Biol, 2000; 32(2):235-41

Zalutski IV, Lukianova NY, Storchai DM, Burlaka AP, Shvets $\mathrm{YV}$, Borikun TV. Influence of exogenous lactoferrin on the oxidant/ antioxidant balance and molecular profile of hormone receptor-positive and -negative human breast cancer cells in vitro. Exp Oncol, 2017; 39:106-111.

Zhang M, Fang B, Chen L. Study on the anti-tumor activity and structural changes of bovine lactoferrin-oleic acid and linoleic acid complex. Chem Eng Trans, 2015; 46:1399-404.

Zhang Y, Lima CF, Rodrigues LR. In vitro evaluation of bovine lactoferrin potential as an anticancer agent. Int Dairy J, 2015; 40:6-15.

\section{How to cite this article:}

EL-Baky NA, Abu-Serie MM, Redwan EM. De novo designed lactoferrin-oleic acid-loaded chitosan nanoparticles with improved activity and selectivity toward four human cancer cells as compared to conventional complexes. J Appl Pharm Sci, 2021; 11(03):060-070. 